\title{
Assessment of groundwater potential zones using multi-influencing factor (MIF) and GIS: a case study from Birbhum district, West Bengal
}

\author{
Raju Thapa $^{1} \cdot$ Srimanta Gupta $^{1}$ (D) Shirshendu Guin ${ }^{1} \cdot$ Harjeet Kaur $^{1}$
}

Received: 15 November 2016/ Accepted: 1 May 2017/Published online: 9 May 2017

(c) The Author(s) 2017. This article is an open access publication

\begin{abstract}
Remote sensing and GIS play a vital role in exploration and assessment of groundwater and has wide application in detection, monitoring, assessment, conservation and various other fields of groundwater-related studies. In this research work, delineation of groundwater potential zone in Birbhum district has been carried out. Various thematic layers viz. geology, geomorphology, soil type, elevation, lineament and fault density, slope, drainage density, land use/land cover, soil texture, and rainfall are digitized and transformed into raster data in ArcGIS 10.3 environment as input factors. Thereafter, multi-influencing factor (MIF) technique is employed where ranks and weights, assigned to each factor are computed statistically. Finally, groundwater potential zones are classified into four categories namely low, medium, high and very high zone. It is observed that $18.41 \%\left(836.86 \mathrm{~km}^{2}\right)$ and $34.41 \%$ $\left(1563.98 \mathrm{~km}^{2}\right)$ of the study area falls under 'low' and 'medium' groundwater potential zone, respectively. Approximately $1601.19 \mathrm{~km}^{2}$ area accounting for $35.23 \%$ of the study area falls under 'high' category and 'very high' groundwater potential zone encompasses an area of $542.98 \mathrm{~km}^{2}$ accounting for $11.95 \%$ of the total study area. Finally, the model generated groundwater potential zones
\end{abstract}

Srimanta Gupta

srimantagupta@yahoo.co.in

Raju Thapa

razoothapa44@gmail.com

Shirshendu Guin

shirshenduguin@gmail.com

Harjeet Kaur

harjeet0909@gmail.com

1 Department of Environmental Science, The University of Burdwan, Burdwan 713104, India are validated with reported potential yield data of various wells in the study area. Success and prediction rate curve reveals an accuracy achievement of 83.03 and $78 \%$, respectively. The outcome of the present research work will help the local authorities, researchers, decision makers and planners in formulating better planning and management of groundwater resources in the study area in future perspectives.

Keywords Remote sensing and GIS · Multi-influencing factor (MIF) technique - Groundwater potential zone . Birbhum · West Bengal · India

\section{Introduction}

In India demand of groundwater resources continuously increases with the advent of industrialisation and population expansions. Hence, assessment, planning and management of groundwater resource become crucial and essential phenomena. Remote sensing and GIS technique facilitate time and cost effective, rapid assessment of groundwater resource, which otherwise through traditional method becomes very costly, laborious and time consuming work (Moore et al. 1991; Krishnamurthy et al. 2000; Jha et al. 2010; Arkoprovo et al. 2012; Hammouri et al. 2012; Lee et al. 2012a; Davoodi et al. 2015). To delineate groundwater potential lineament and hydrogeomorphology, groundwater level decline and its impacts on regional subsidences and karst hazards, and groundwater vulnerability to pollution are applied by GIS-based approaches by several researchers (Nag 2005; Taheri et al. 2015; Singh et al. 2015; Taheri et al. 2016). In delineation of groundwater potential zone 
various factors such as lineament, faults and hydrogeomorphology (Nag 2005; Senthil-Kumar and Shankar 2014; Singh et al. 2014; Taheri et al. 2015), rainfall, soil, lithology and soil texture (Magesh et al. 2012), slope, elevation (Magesh et al. 2011; Thomas et al. 2012), drainage systems (Rassam et al. 2008; Preeja et al. 2011; Dabral et al. 2013) and groundwater table distribution (Arkoprovo et al. 2012) play a crucial role.

So far, various techniques have been adopted by various researchers such as, frequency ratio (Manap et al. 2014; Razandi et al. 2015), multi-criteria decision evaluation (MCDE) (Murthy and Mamo 2009; Machiwal and Singh 2015; Jothibasu and Anbazhagan 2016), artificial neural network (ANN) (Lee et al. 2012b), random forest model (Naghibi et al. 2016; Zabihi et al. 2016) logistic regression model (Pourtaghi and Pourghasemi 2014) and analytic hierarchy process (AHP) (Adiat et al. 2012). Most of the bivariate and multivariate statistical techniques have their drawbacks in making assumptions prior to investigation and sensitivity towards outlier values (Abrahart et al. 2008; Tehrany et al. 2013; Umar et al. 2014). In this context, multi-influencing factor technique (MIF) is rather a simple, effective and reliable technique for delineating groundwater potential zones (Shaban et al. 2006; Magesh et al. 2012; Selvam et al. 2014).

In Birbhum district, four blocks namely Murarai II, Nalhati II, Rampurhat II and Nanoor have been categorized as semi-critical, based on the long-term trend of water table fluctuations in pre and post monsoon and stages of groundwater development (CGWB 2009). The district receives its major share of rainfall during monsoon season while remains comparatively dry during rest of the year. Overall, this district experiences a high fluctuation in water table level and the temperature shoots well above $45^{\circ} \mathrm{C}$ in the summer season. Farmers suffer from acute shortage of irrigation water (Nag and Ray 2015) as most of the surface streams dry up seasonally and compel to depend on groundwater resources to a great extent. Over-exploitation of groundwater has also led to fluoride contamination in both water table aquifer and confined aquifer of groundwater in some parts of the Birbhum district (PHED report 2007; Mondal et al. 2014; Thapa et al. 2016). In this context, demarcating groundwater potential zone is essential to locate high groundwater potential areas for future consumptive use. The present study aims to elucidate the groundwater potential zone within Birbhum district with the help of remote sensing, and MIF techniques. The results of the present study can serve as first-hand information to planners, policy makers and local authorities for future planning projects to ensure sustainable utilization of groundwater resources.

\section{Study area}

Birbhum, also known as the 'Land of Red Soil', is well known for its culture values. The district with its shape similar to isosceles triangles encompasses an area of $4545 \mathrm{~km}^{2}$ lying within $23^{\circ} 32^{\prime} 30^{\prime \prime}$ and $24^{\circ} 35^{\prime} 0^{\prime \prime}$ North latitude and $88^{\circ} 1^{\prime} 40^{\prime \prime}$ and $87^{\circ} 5^{\prime} 25^{\prime \prime}$ East longitude (Fig. 1). The base of this triangle is marked by river Ajoy separating the boundary of Birbhum with Burdwan district. On the west and north, the district is bounded by the Jharkhand state of India and shares its eastern boundary with districts of Murshidabad and Burdwan of West Bengal. Birbhum district falls under Lower Gangetic plain region as per agro-climatic classification with the majority of soil being red laterite with low alluvium and/or clay content.

\section{Geological and hydrogeological framework}

Chottanagpur Gneissic Complex marks the metamorphic basement rocks which comprise of pink granite, granite gneiss and epidote granite with veins of quartz and pegmatite (Mukherjee et al. 1969; Sen et al. 1987; Sen and Vijaya 2005; Mondal et al. 2014) and are exposed in the south-west and north-west part of the district. With moderate dip towards the northeast, foliation is generally trending in NW-SE directions. Early Cretaceous Rajmahal Trap Formation consisting of gray, hard and compact basalt with a network of siliceous veins and zeolites are exposed in the northern part. Tertiary deposits consisting of claystone with silty and sandy layers with variegated colors are exposed in patches in eastern and south-eastern part of the district. Along the stream course, a recent Quaternary deposit consisting mostly if clayey soil/alluvium of yellowish gray to khaki gray color with iron nodules along with sandy sludge of medium to coarse grain size with pebbles and boulders bed at the base are observed (Sen and Vijaya 2005; Mondal et al. 2014).

In Birbhum district, groundwater occurs in both confined and water-table conditions with resultant flow direction from west to east. Groundwater under water table condition occurs in both alluvium and hard rock terrains whereas a confined condition occurs under the deep alluvium aquifer where the confined aquifer's piezometric head vary 3-4 m bgl (meter below ground level) on an average (Mondal et al. 2014). The deeper tube well in the east generally has higher yield in comparison to the western zones with shallower tube wells (Mondal et al. 2014). Recent alluviums of quaternary age group bearing porous formations are fairly thick and are spreading over an area of $210 \mathrm{~km}^{2}(4.5 \%)$ of the total area in the southern and south-eastern part have very large yield prospects of about $200 \mathrm{~m}^{3} / \mathrm{h}$. Older alluvium and older alluvium with 
Fig. 1 Location map of the study area

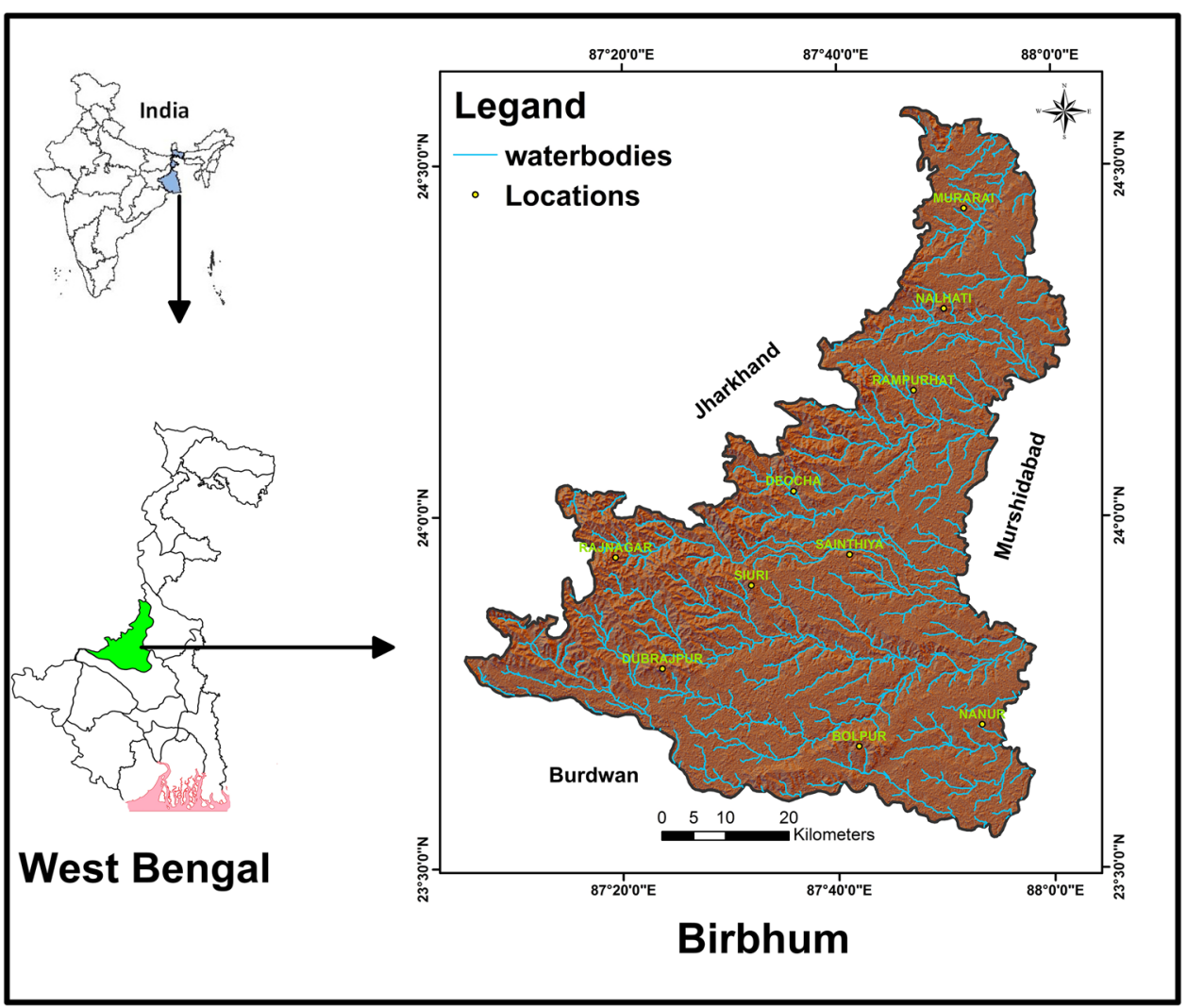

laterites, etc. belonging to upper tertiary to lower quaternary age group accounts for approximately 48 and $29 \%$ of the study area, respectively. Older alluviums are associated with moderate yield prospects of about $70-180 \mathrm{~m}^{3} / \mathrm{h}$ where very limited yield prospects of below $50 \mathrm{~m}^{3} / \mathrm{h}$ are observed in older alluvium with laterites, etc. types of aquifers. Basalt with Intertrapean Clay of Mesozoic-Palaeozoic age occurs at the western end and Gneiss and associated rocks of Archean age have very restricted groundwater yield of below $10 \mathrm{~m}^{3} /$ day as groundwater are restricted to weathered residuum only along with fracture zones having secondary porosity.

Rainfall is the principle source of recharge, supplemented by influent seepage from the irrigation canal network. Well, hydrographs show that recharge from rainfall occur very fast and keep pace with the increasing or decreasing rainfall in this area. Fluctuation of water table is generally constant in the eastern region in comparison to the western region. The tube wells in the east (100 m deep on an average) are deeper in comparison to the western part of the district (Mondal et al. 2014). Several blocks in Birbhum district are affected with fluoride occurrence in groundwater (PHED 2007; Mondal et al. 2014; Thapa et al. 2016).

\section{Methodology}

The methodology adopted for the present study is shown in Fig. 2. The base map of Birbhum district was prepared based on Survey of India toposheet (1:50,000 scale). Various thematic layers viz. geology, geomorphology, lineament and fault density, drainage density, rainfall, soil type, slope, elevation, land use/land cover, and soil texture were used to carry out the study. The geology and geomorphology map were digitized from district resource map series of Geological Survey of India (GSI). Soil type, land use land cover, rainfall were georeferenced and digitized from district planning map series of NATMO, 2004. The soil texture map was collected from official Birbhum portal (http://birbhum. gov.in). Lineament and fault density map were generated from Bhuvan thematic map portal and BMPTC Atlas. Cartosat-1 (CartoDEM, spatial resolution $2.5 \mathrm{~m}$ ) has been used to derive drainage density, elevation and slope map of the study area. Slope map of the Birbhum district was generated using 'raster surface' function of 3D analyst tool and the drainage density was generated with the help of 'line density' under spatial analyst tool in ArcGIS 10.3 software. 
Fig. 2 Flowchart of methodology followed for delineating the groundwater potential zone in Birbhum District, West Bengal, India

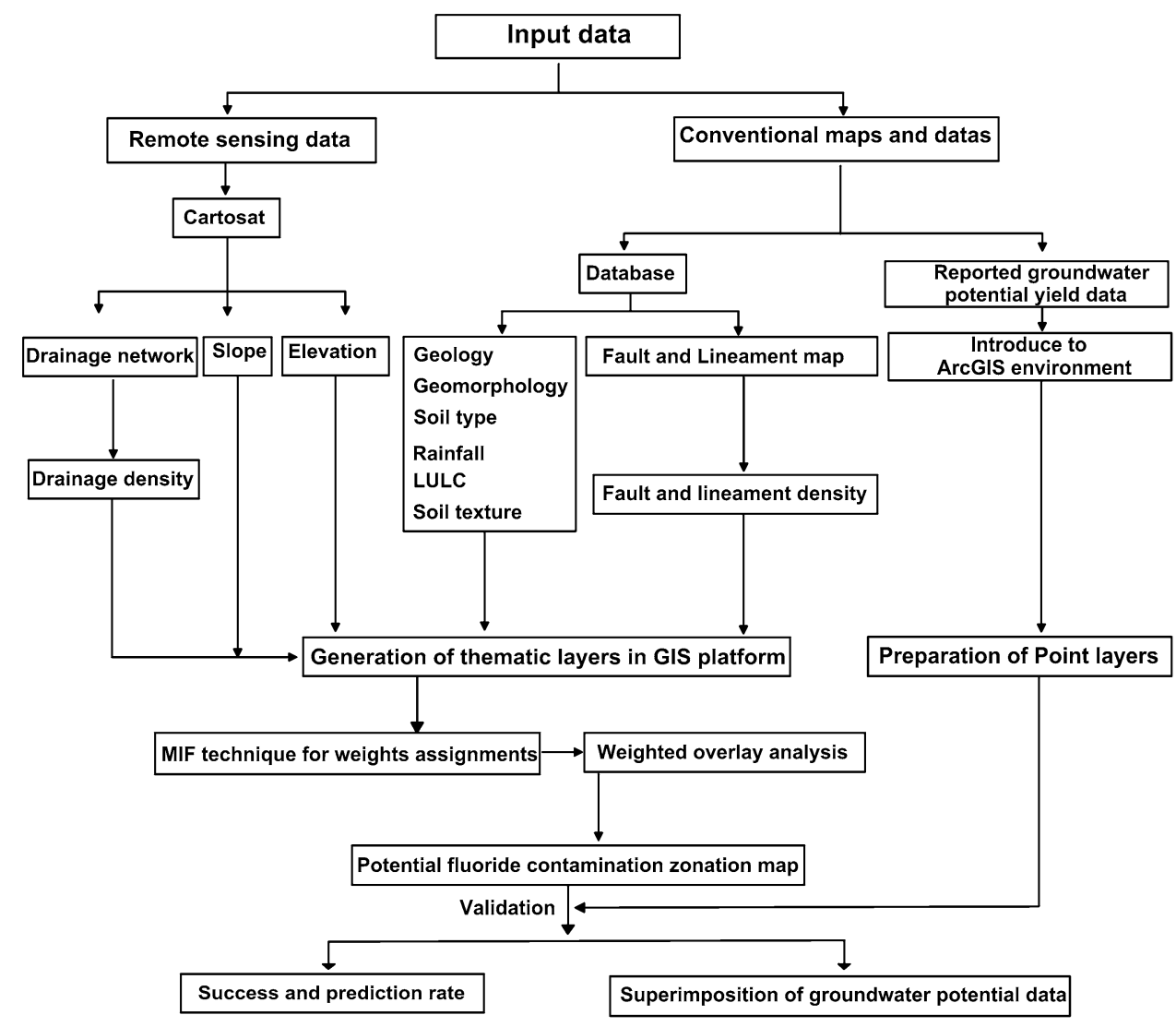

\section{Assigning of weights and ranks}

The weights of each factor were computed statistically using multi-influencing factor (MIF) technique followed by heuristic approaches/knowledge driven method for assigning ranks to each sub-classes of factor maps. The interrelationship among factors classes (Fig. 3) and assigning of ranks to factor's sub-classes was established based on author's expertise as well as literature review (Kaliraj et al. 2014; Senthil-Kumar and Shankar 2014; Dinesan et al. 2015; Razandi et al. 2015; Taheri et al. 2015; Taheri et al. 2016; Jothibasu and Anbazhagan 2016; Senanayake et al. 2016; Thapa et al. 2016; Zabihi et al. 2016). Factors having major influence were marked as major effect and were assigned a weight of 1.0 whereas, minor influence were marked as a minor effect with a weight of 0.5 as shown in Table 1 (Magesh et al. 2012). Table 2 represents relative rates of each factor calculated by the cumulative sum of both major and minor effect followed by proposed score calculation of each influencing factor using the formula as follows:

Proposed Score $=\left[\frac{(X+Y)}{\sum(X+Y)}\right] \times 100$,

where $X$ represents the major effect of factors and $Y$ represents the minor effect of factors.

\section{Weighted overlay method}

After assigning weights and ranks to factors and their subclasses, all the inputs were integrated through weighted overlay method using the Eq. (1):

$$
\begin{aligned}
\mathrm{GWPZ}= & \sum_{i}^{n} \mathrm{G}_{x} \mathrm{G}_{y}+\mathrm{GM}_{x} \mathrm{GM}_{y}+\mathrm{S}_{x} \mathrm{~S}_{y}+\mathrm{LULC}_{x} \mathrm{LULC}_{y}+\mathrm{DD}_{x} \mathrm{DD}_{y} \\
& +\mathrm{Sl}_{x} \mathrm{Sl}_{y}+\mathrm{E}_{x} \mathrm{E}_{y}+\mathrm{R}_{x} \mathrm{R}_{y}+\mathrm{FL}_{x} \mathrm{FL}_{y}+\mathrm{ST}_{x} \mathrm{ST}_{y}
\end{aligned}
$$

where GWPZ represents the groundwater potential zonation, ' $x$ ' and ' $y$ ' represents factor maps and factor subclass, respectively, G represents geology, GM represents geomorphology, $\mathrm{S}$ is soil, LULC is land use land cover, DD is drainage density, $\mathrm{Sl}$ is slope, $\mathrm{E}$ is elevation, $\mathrm{R}$ is Rainfall, FL is fault and lineament density and ST is the soil texture.

\section{Results and discussion}

\section{Input parameters for MIF}

Geology

Geology plays a vital role in determining the groundwater potential of an area. The porosity of rocks, alluvium/ 
Fig. 3 Interrelationship between the multi-influencing factors concerning the groundwater potential zone in Birbhum, West Bengal

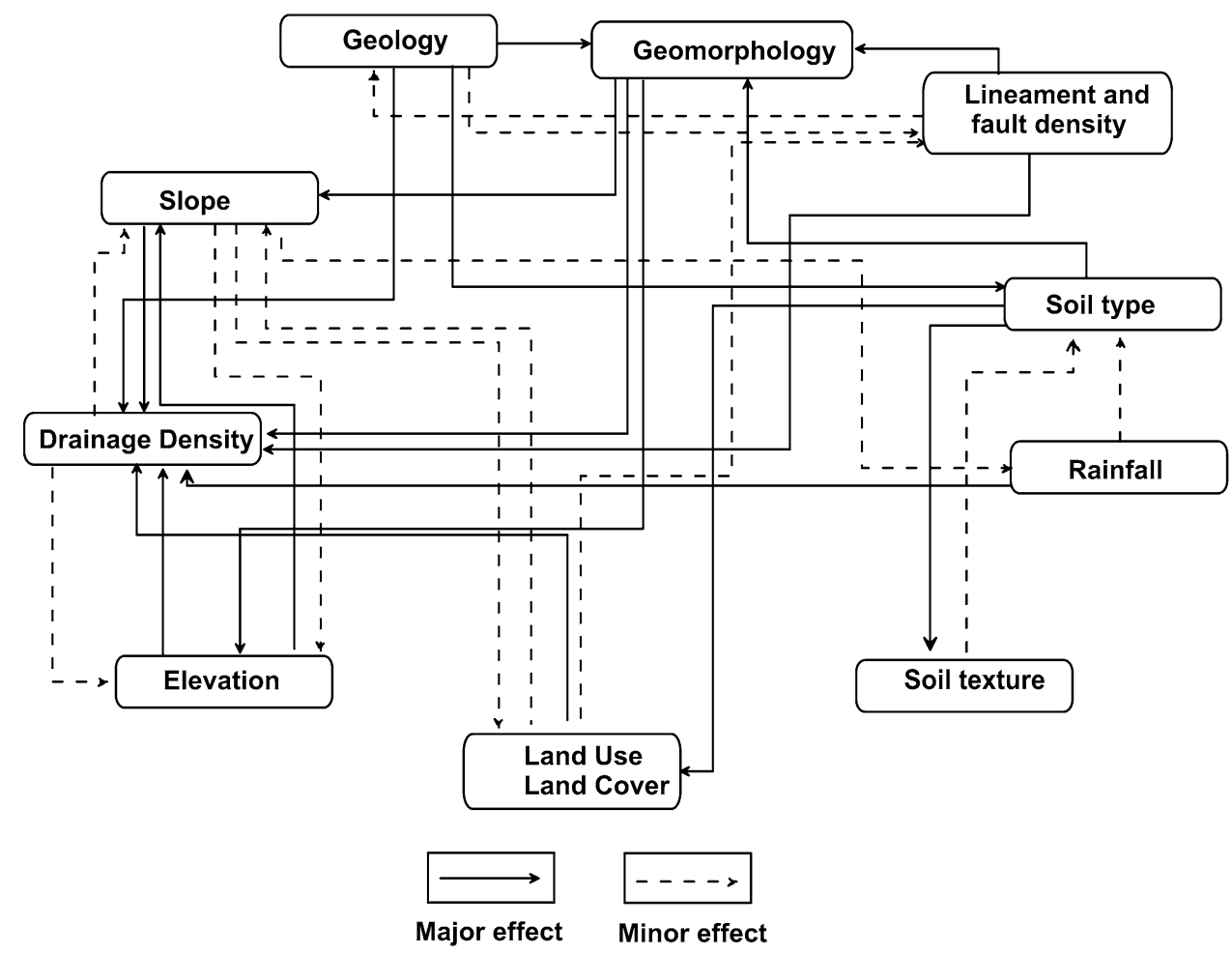

Table 1 Effect of influencing factor, relative rates and score for each potential factor (Magesh et al. 2012)

\begin{tabular}{|c|c|c|c|c|}
\hline Factor & Major effect $(A)$ & Minor effect $(B)$ & $\begin{array}{l}\text { Proposed relative } \\
\text { rates }(A+B)\end{array}$ & $\begin{array}{l}\text { Proposed score of each } \\
\text { influencing factor }\end{array}$ \\
\hline Geology & 3 & 0.5 & 3.5 & 17 \\
\hline Lineament and fault density & 2 & 0.5 & 2.5 & 12 \\
\hline Geomorphology & 3 & 0 & 3 & 14 \\
\hline Drainage Density & 0 & 1 & 1 & 5 \\
\hline Slope & 1 & 1.5 & 2.5 & 12 \\
\hline LULC & 1 & 0.5 & 1.5 & 7 \\
\hline Elevation & 2 & 0 & 2 & 10 \\
\hline Rainfall & 1 & 0.5 & 1.5 & 7 \\
\hline Soil type & 3 & 0 & 3 & 14 \\
\hline Soil texture & 0 & 0.5 & 0.5 & 2 \\
\hline Total & & & $\mathbf{\Sigma} 21$ & $\mathbf{\Sigma} 100$ \\
\hline
\end{tabular}

sediment cover, sand, silt, clay bed, etc. governs the infiltration and percolation of water flow. Shaban et al. (2006) referred that groundwater recharge is greatly influenced by the rocks types, exposed to the surface. In the study area, hard clay with impregnated caliche nodule, granite-gneiss complex (Chotanagpur Gneissic), laterite, an alternating band of sand, silt and clay encompassed an area of $1760 \mathrm{~km}^{2}(38 \%), 712.58 \mathrm{~km}^{2}(15 \%), 1116 \mathrm{~km}^{2}(24 \%)$ and $833.39 \mathrm{~km}^{2}(18 \%)$, respectively, as represented in Fig. 4a. Rajmahal trap (basalt), Gondwana Supergroup, pegmatite and unclassified metamorphosis account for a very small portion of the study area encompassing an area of 141.63,
49.39, 0.69 and $7.08 \mathrm{~km}^{2}$ accounting for $3,1,1.5$ and $0.15 \%$, respectively.

\section{Geomorphology}

Geomorphology and its features are essential components for understanding landforms evolutions controlling the movement and occurrence of groundwater. Geology provides crucial information about the underlying geological setup and the topographic feature hence widely used in groundwater-related studies (Machiwal et al. 2011). Weathered and fractured hard rock terrains with higher 
Table 2 Classification of weighted factors influencing the potential zones in the study area

\begin{tabular}{|c|c|c|c|}
\hline Factor & Subclass & Weight & Rating \\
\hline \multirow[t]{8}{*}{ Geology } & Alternating band of sand, silt and clay & 17 & 17 \\
\hline & Gondwana Super Group & & 14 \\
\hline & Granite Gneiss with enclave of metamorphites & & 7 \\
\hline & Hard Clay impregnated with caliche nodules & & 4 \\
\hline & Laterite and lateritic soil & & 5 \\
\hline & Pegmatite & & 3 \\
\hline & Rajmahal trap-Basalt & & 10 \\
\hline & Unclassified metamorphics & & 1 \\
\hline \multirow[t]{4}{*}{ Geomorphology } & Old floodplain & 14 & 14 \\
\hline & Upper mature deltic plain and paradeltic fan surfaces & & 10 \\
\hline & Hills and valleys of Rajmahal trap & & 5 \\
\hline & Pediplain/peneplain & & 7 \\
\hline \multirow[t]{7}{*}{ LULC } & Rural settlements & 7 & 2 \\
\hline & Urban settlement & & 1 \\
\hline & Industrial land & & 1 \\
\hline & Wasteland & & 2 \\
\hline & water bodies & & 7 \\
\hline & Forest & & 5 \\
\hline & Cultivated land & & 6 \\
\hline \multirow[t]{6}{*}{ Elevation } & $0-35 \mathrm{~m}$ & 10 & 10 \\
\hline & $35-48 \mathrm{~m}$ & & 9 \\
\hline & $48-63 \mathrm{~m}$ & & 8 \\
\hline & $63-80 \mathrm{~m}$ & & 6 \\
\hline & $80-100 \mathrm{~m}$ & & 3 \\
\hline & $100-158 \mathrm{~m}$ & & 2 \\
\hline \multirow[t]{4}{*}{ Drainage Density } & Very low & 5 & 1 \\
\hline & Medium & & 4 \\
\hline & Low & & 2 \\
\hline & High & & 5 \\
\hline \multirow[t]{5}{*}{ Rainfall } & Very low & 7 & 1 \\
\hline & Low & & 3 \\
\hline & Medium & & 5 \\
\hline & High & & 6 \\
\hline & Very high & & 7 \\
\hline \multirow[t]{5}{*}{ Soil type } & Red loamy & 14 & 2 \\
\hline & Red sandy & & 8 \\
\hline & Younger alluvial & & 14 \\
\hline & Laterite & & 12 \\
\hline & Old alluvial & & 14 \\
\hline \multirow[t]{6}{*}{ Soil texture } & Clay loam & 2 & 1 \\
\hline & Loam & & 2 \\
\hline & Clay & & 1 \\
\hline & Sandy & & 2 \\
\hline & Sandy loam & & 2 \\
\hline & Sandy clay loam & & 2 \\
\hline \multirow[t]{3}{*}{ Lineament and fault density } & High & 12 & 12 \\
\hline & Medium & & 7 \\
\hline & Low & & 5 \\
\hline \multirow[t]{3}{*}{ Slope } & Low & 12 & 12 \\
\hline & Moderate & & 8 \\
\hline & High & & 4 \\
\hline
\end{tabular}




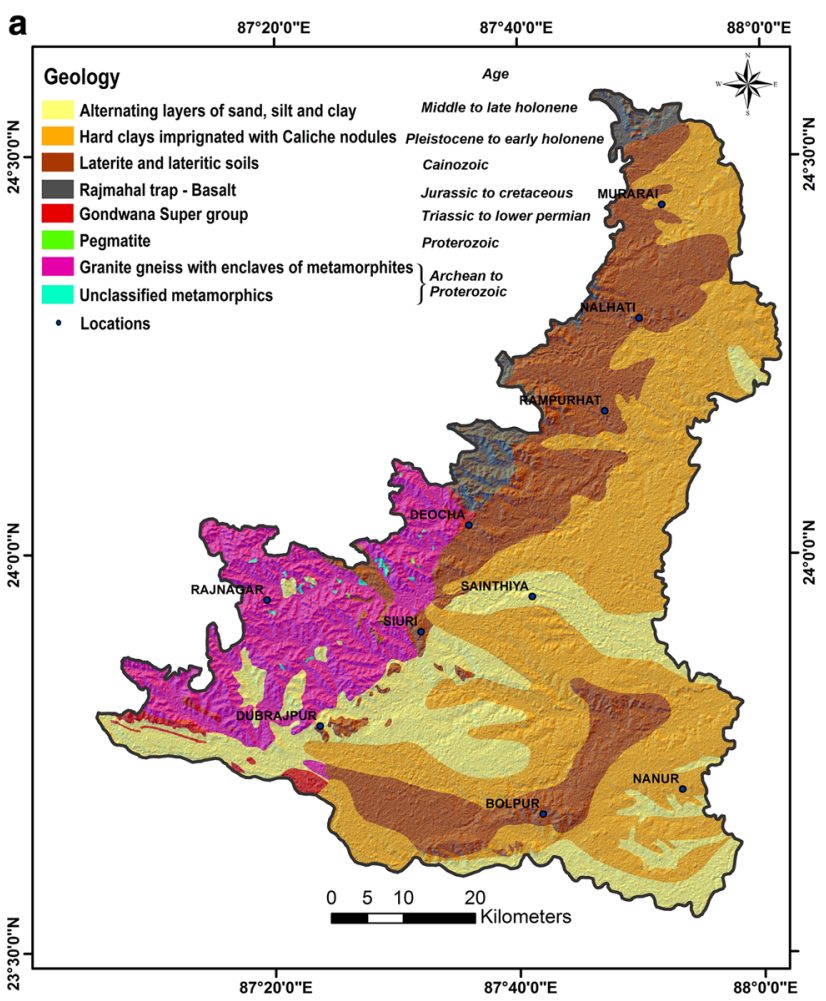

Fig. 4 Various input parameters a Geology of the study area, b geomorphology map of the study area, c Soil type of the study area, d land use land cover of the study area, $\mathbf{e}$ drainage density of the study

elevations and steeper topography have medium to low groundwater potential, whereas floodplain zones are usually associated with good groundwater potential due to the high infiltration rates of the alluvium deposits. In the study area, upper mature deltaic plain and old flood plain, covering an area of 2375.29 and $621.25 \mathrm{~km}^{2}$, account for 51.41 and $13.45 \%$, respectively, of the total study area. Rajmahal trap accounts for $144.74 \mathrm{~km}^{2}$, which is about $3.13 \%$ of the study area and pediplain $\left(1479.27 \mathrm{~km}^{2}\right)$ represents $32.02 \%$ of the total area (Fig. 4b).

\section{Soil type}

The permeability of the soil is directly related to the effective porosity of the soil and is greatly influenced by grains shape, size grains, adsorbed water, voids ratio, the degree of saturation and impurities present (Punmia et al. 2005). The soil is an important factor for delineating the groundwater potential zones. The analysis of the soil type reveals that the study area is covered with different soil types namely, red loamy, red sandy, younger alluvial, laterite and old alluvial occupying area of about $829 \mathrm{~km}^{2}$ (17\%), $261 \mathrm{~km}^{2}(6 \%), 318 \mathrm{~km}^{2}$ (7\%), $2236 \mathrm{~km}^{2}$ (48\%) and $977 \mathrm{~km}^{2}(21 \%)$, respectively (Fig. 4c).

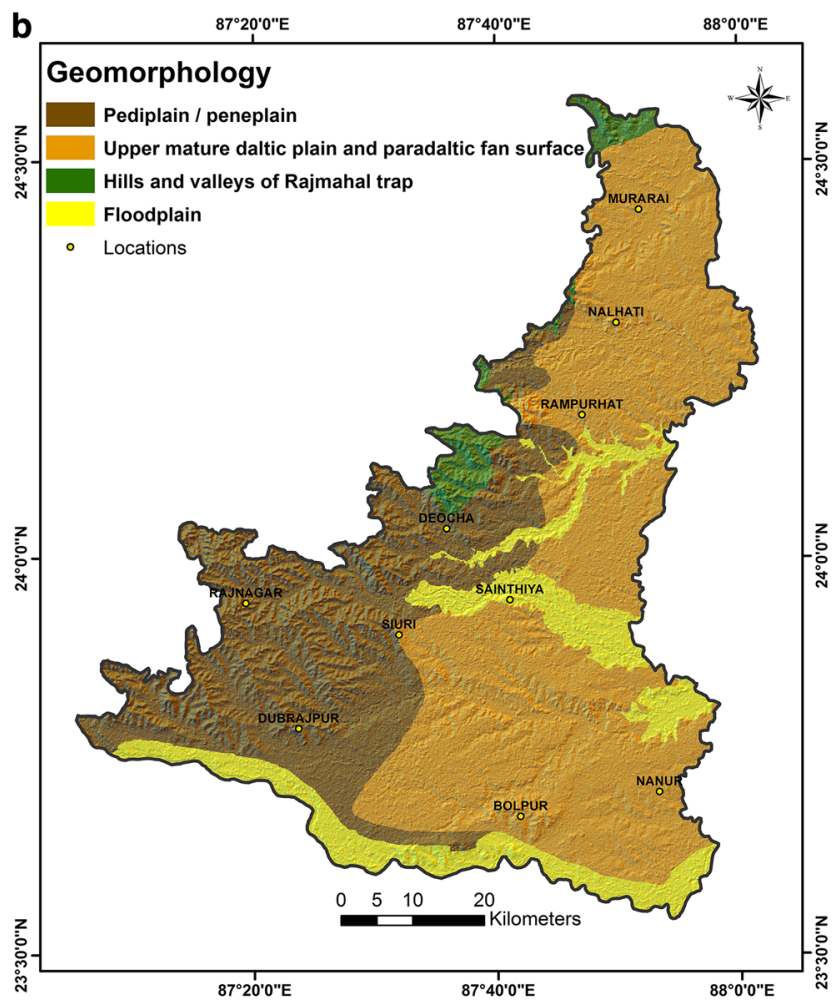

area, $\mathbf{f}$ slope of the study area, $\mathbf{g}$ elevation in the study area, $\mathbf{h}$ spatial distribution of rainfall in the study area, $\mathbf{i}$ lineament and fault density of the study area, $\mathbf{j}$ soil texture of the study area

\section{Land use/land cover (LULC)}

Land use/cover plays a crucial role in groundwater recharge. Shaban et al. (2006) mentioned that vegetation cover influences the groundwater recharge by preventing water loss by absorbing water. The major land use type of study area are rural settlements, urban settlements, industrial land, wasteland, water bodies, forest and cultivated land occupying area of $466 \mathrm{~km}^{2}(10 \%), 43 \mathrm{~km}^{2}$ (1\%), $46 \mathrm{~km}^{2}$ (1\%), $42 \mathrm{~km}^{2}(1 \%), 113 \mathrm{~km}^{2}$ (2\%), $168 \mathrm{~km}^{2}$ (4\%) and $3743 \mathrm{~km}^{2}(81 \%)$, respectively (Fig. 4d).

\section{Drainage density}

Drainage density is characterized as the closeness of spacing of stream channels. Krishnamurthy et al. (2000) mentioned that natural drainage systems are the indicator of terrain's higher permeability and porosity. According to drainage density, the study area is divided into four subclasses, i.e., very low, low, medium and high, covering an area of 144.38, 1331.14, 1995.77 and $1149.42 \mathrm{~km}^{2}$ accounting for 3, 28.81, 43.19 and $24.90 \%$, respectively, of the total area (Fig. 4e). 

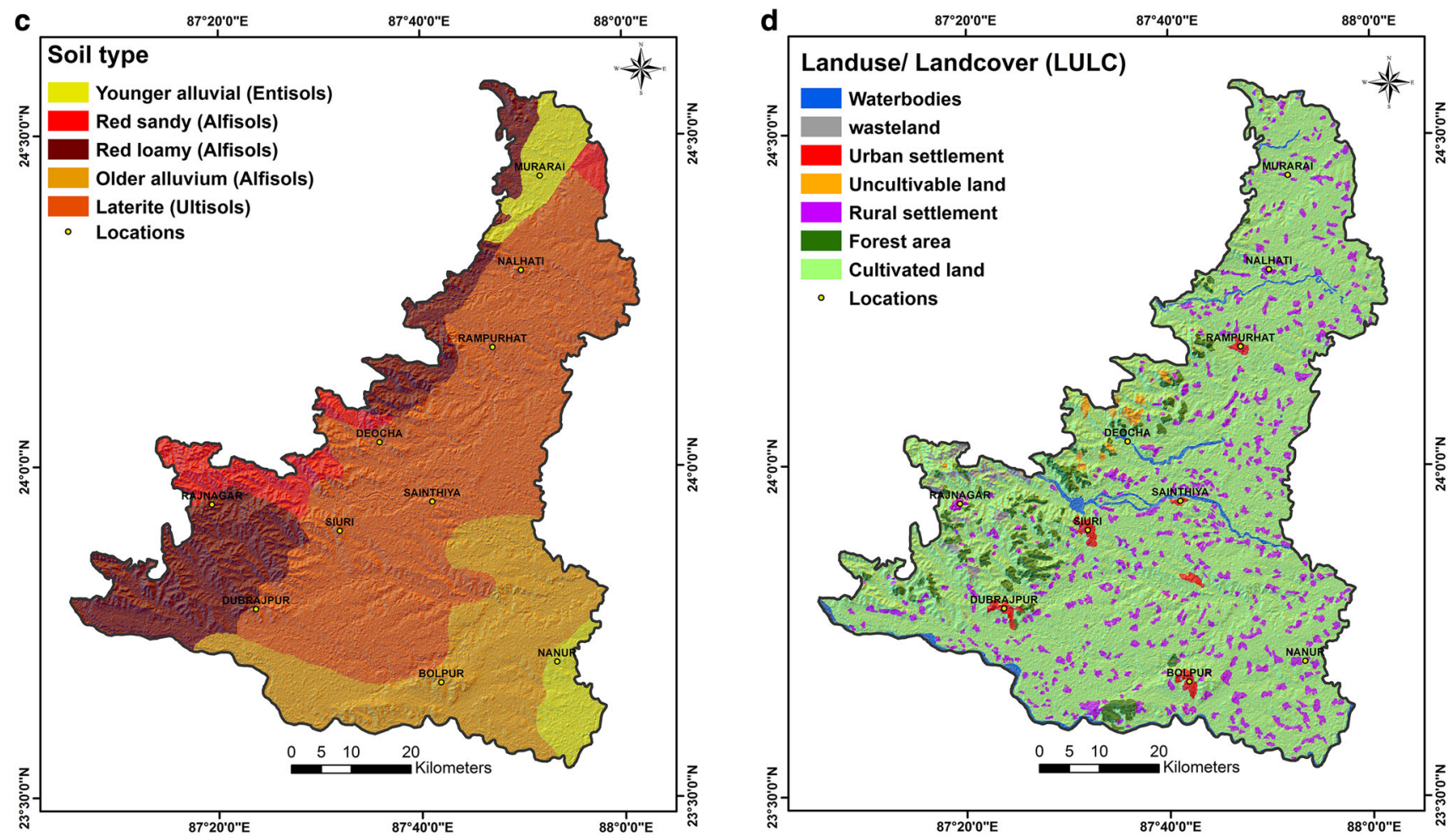

Fig. 4 continued
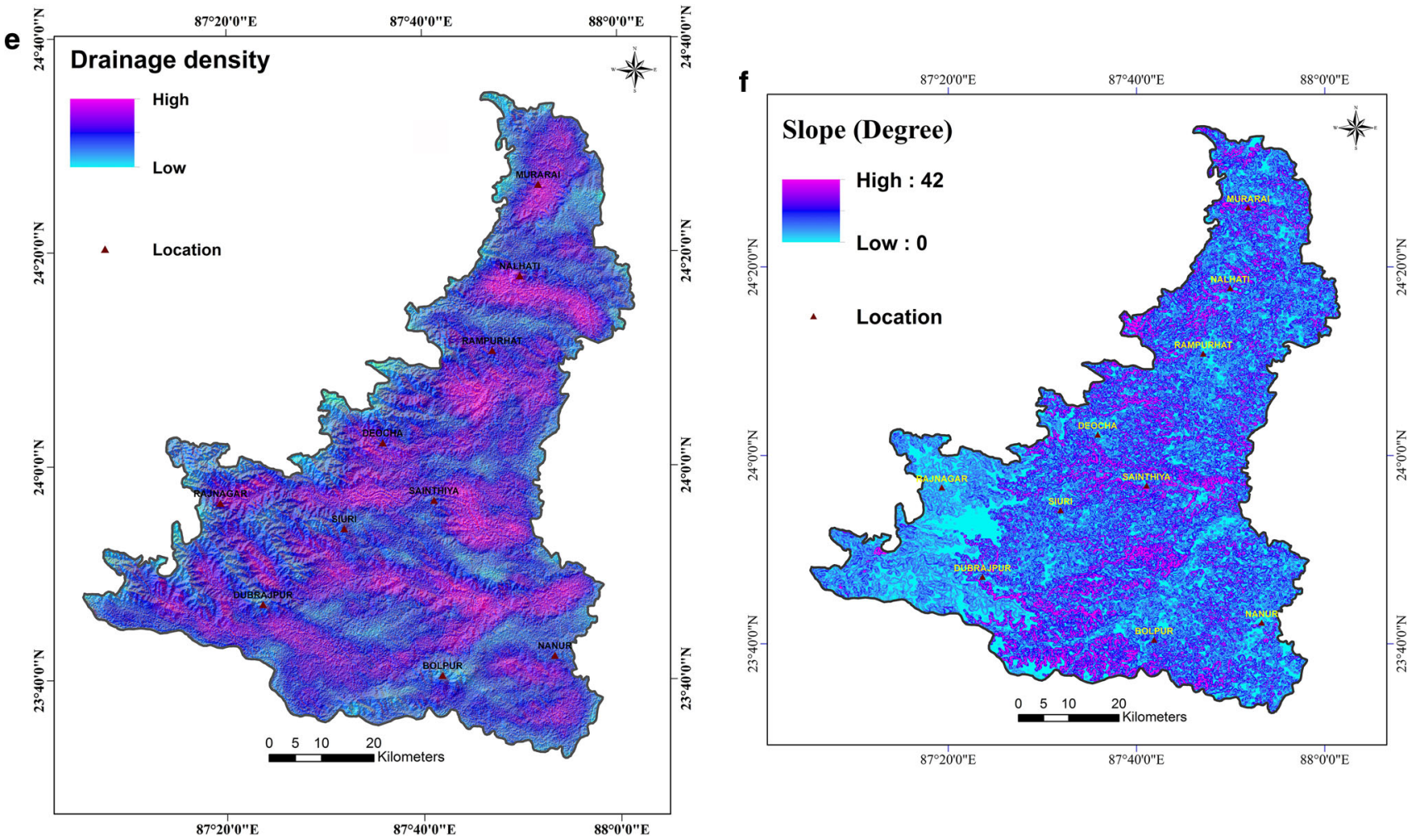

Fig. 4 continued 

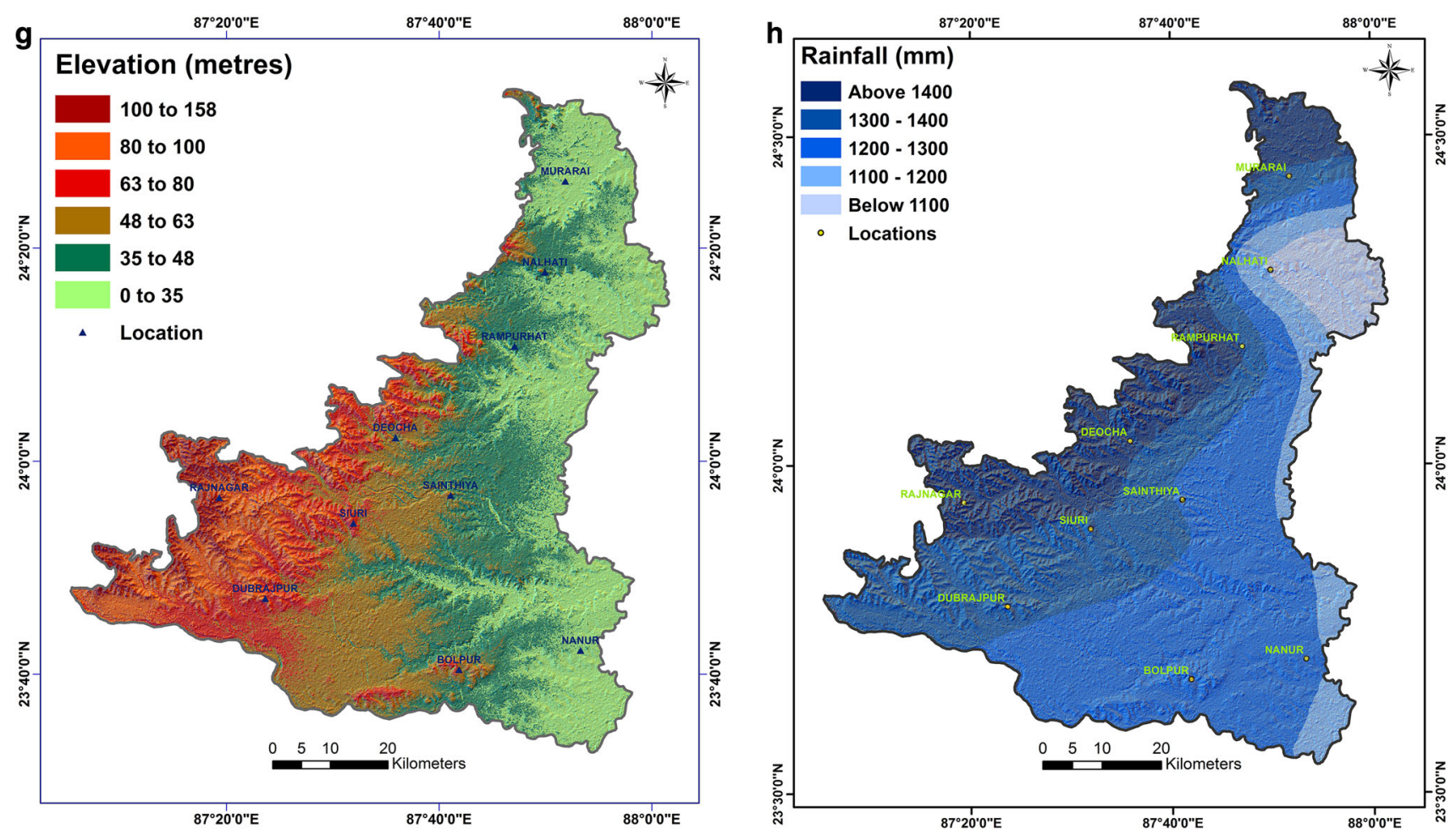

Fig. 4 continued
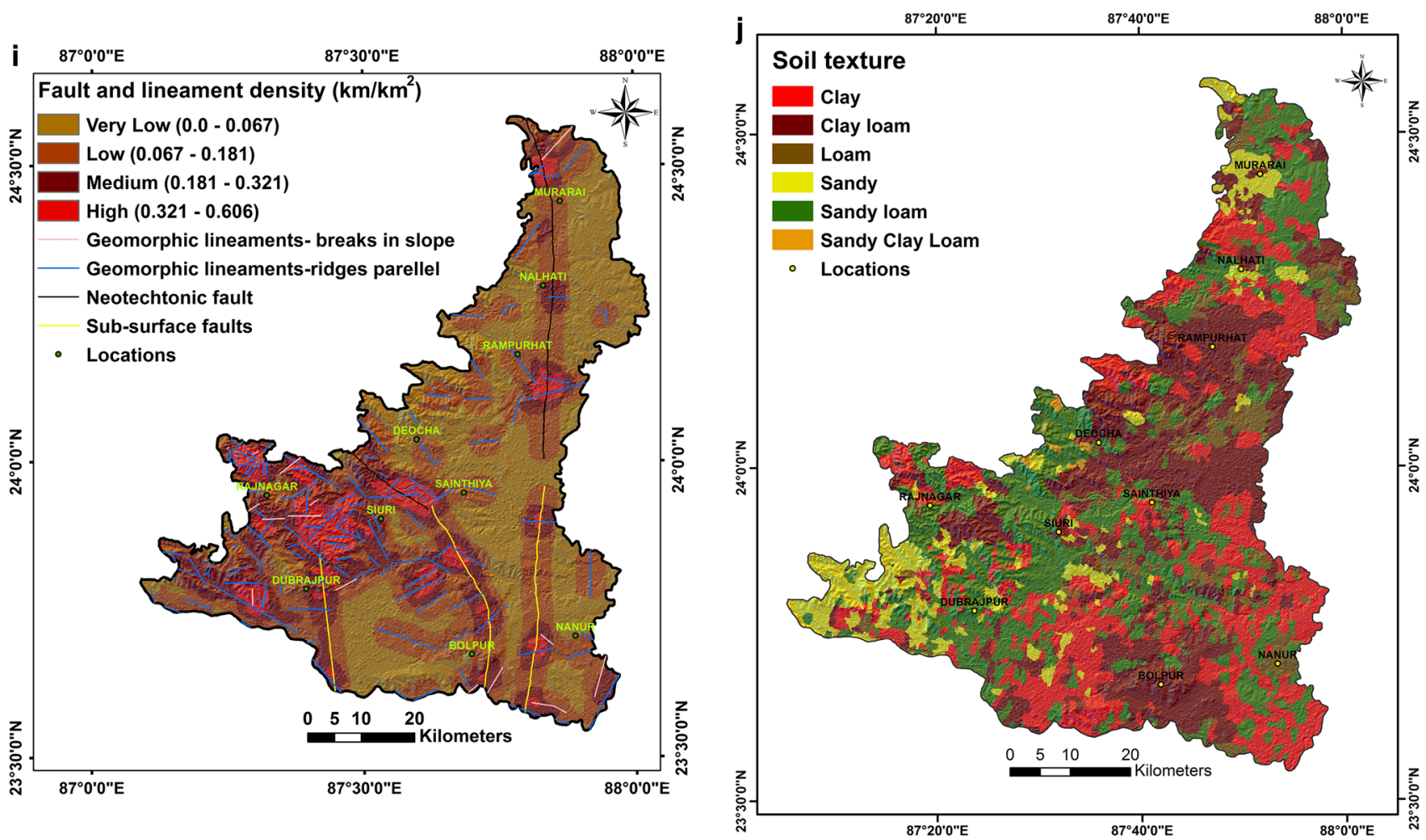

Fig. 4 continued 
Fig. 5 Groundwater potential zonation in the Birbhum district, West Bengal

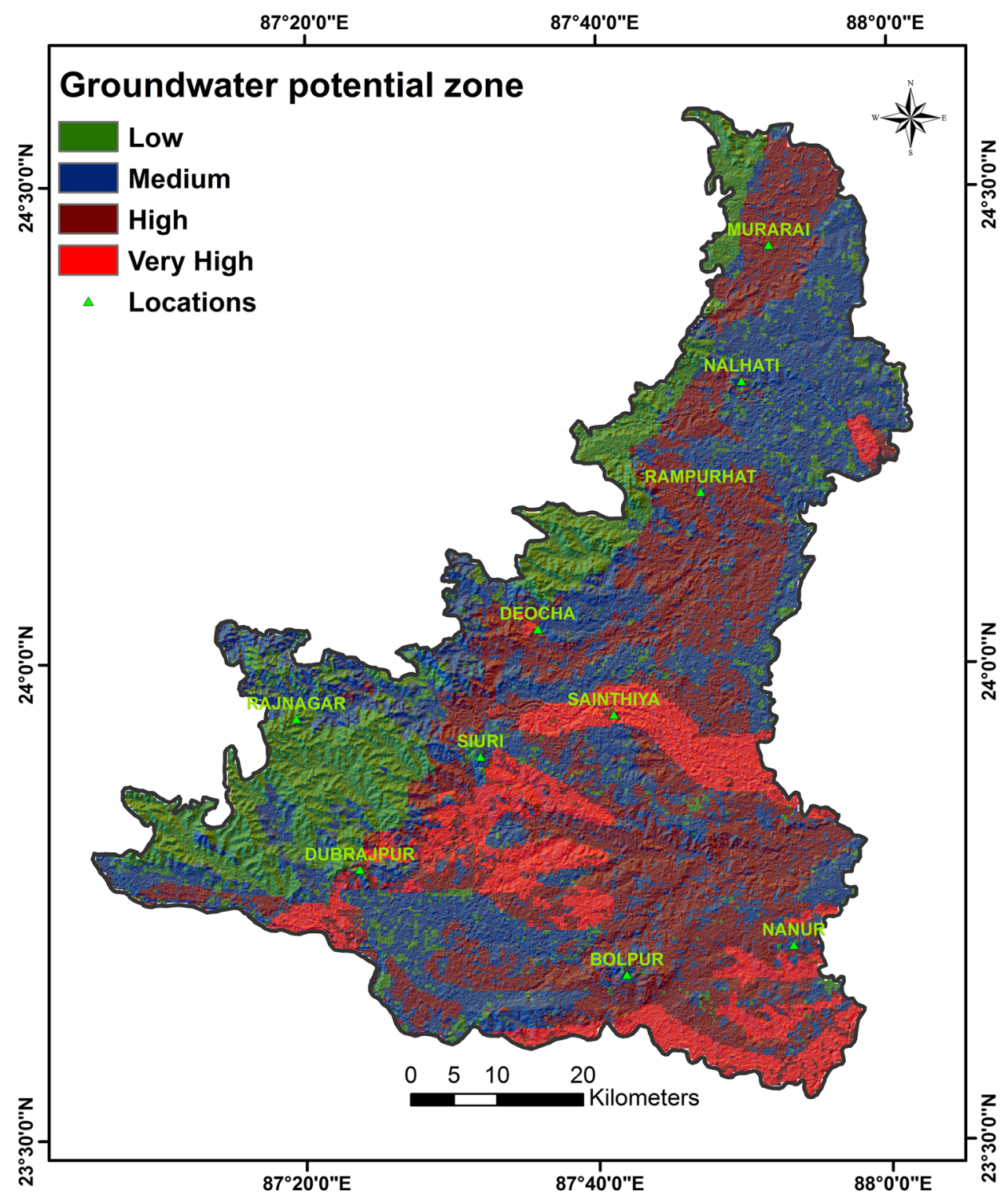

\section{Slope}

Infiltration of surface water is directly influenced by the slope gradient. Steep slopes result in rapid downward water flow resulting from insufficient time to infiltrate. Flat areas provide higher retention time for infiltration of rainwater. The majority of the portion of the study area falls under gentle slope category with a slope less than $10^{\circ}$. On the basis of slope angle, the entire study area is divided into three sub-classes, i.e., slope $<10^{\circ}, 10^{\circ}-20^{\circ}$ and $20^{\circ}-80^{\circ}$, respectively, covering an area of $3897.02 \mathrm{~km}^{2}(84.34 \%)$, $598.29 \mathrm{~km}^{2}(12.15 \%)$ and $125.40 \mathrm{~km}^{2}$ (2.71\%) (Fig. 4f).

\section{Elevation}

Elevation of the study area has a major role in groundwater potential. Plainer areas, having lower elevation tend to retain water longer inducing greater infiltration of recharge of water. A large amount of runoff and a smaller amount of infiltration are associated with areas with steep elevation angle. It is subdivided into six subclasses namely 0-35, 35-48, 48-63, 63-80, 80-100 and 100-158 m (Fig. 4g).

\section{Rainfall}

Rainfall is one of the most important sources of groundwater recharge through percolation in the groundwater system. The average annual rainfall in the study area is grouped into five classes namely very low (below $1100 \mathrm{~mm})$, low (1100-1200 mm), medium (1200-1300 mm), high (1300-1400 mm) and very high (above $1400 \mathrm{~mm}$ ), covering the area of about $240 \mathrm{~km}^{2}$ (5\%), $383 \mathrm{~km}^{2}$ (8\%), $1867 \mathrm{~km}^{2}$ (40\%), $1199 \mathrm{~km}^{2}(26 \%)$ and $931 \mathrm{~km}^{2}$ (20), respectively (Fig. 4h). Rainfall 
Fig. 6 Superimposition of groundwater potential data reported by CGWB over the final derived groundwater potential zonation map

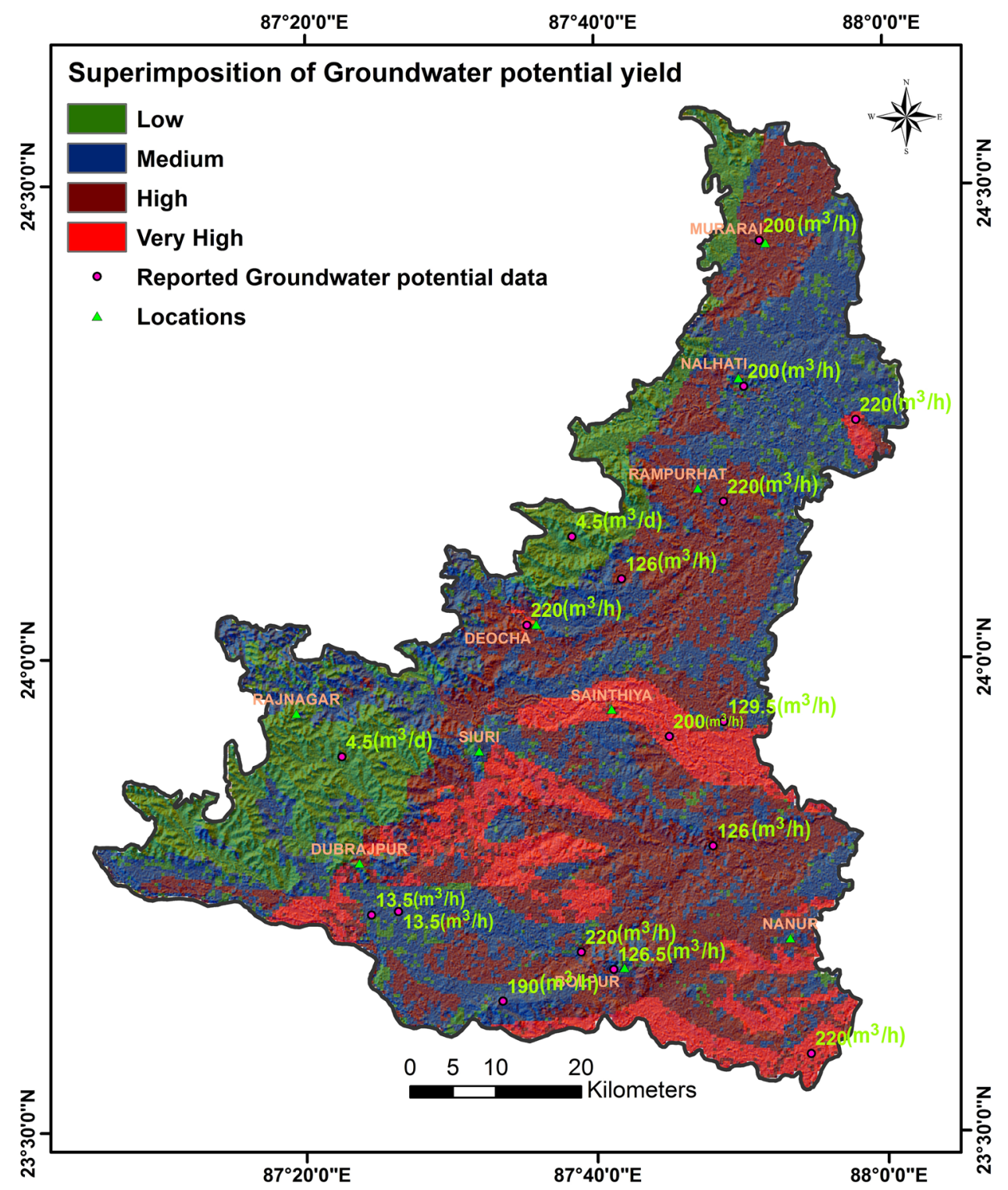

distribution along with the slope gradient directly affects the infiltration rate of runoff water hence, increases the possibility of groundwater potential zones.

\section{Lineament and fault density}

Higher fault and lineament density can be used to speculate secondary porosity as most of the faults or fracture system serves as conduits for movement and storage of groundwater. Krishnamurthy et al. (2000) pointed out that a buffer zone of $300 \mathrm{~m}$ around fracture system of faults and lineaments are treated as appropriate groundwater recharge and availability zone. The lineament and fault density map in the study area was categorized into four, i.e., very $\mathrm{km}^{2}$ area, respectively (Fig. 4i).
Soil texture

Soil texture has a valuable role in groundwater potential. High permeability levels are observed in gravels and coarse sand; fine sand and loamy soils exhibit moderate permeability whereas lowest permeability is shown by clay and silt soils (Saunders 2001). Soil texture in the study area is subdivided into six subclasses namely, clay loam, loam, clay, sandy, sandy loam and sandy clay loam, occupying area about $1330 \mathrm{~km}^{2}$ (29\%), $339 \mathrm{~km}^{2}(7 \%), 1140 \mathrm{~km}^{2}(25 \%), 408 \mathrm{~km}^{2}$ (9\%), $1389 \mathrm{~km}^{2}(30 \%), 14 \mathrm{~km}^{2}(0.5 \%)$, respectively (Fig. $\left.4 \mathrm{j}\right)$.

\section{Potential groundwater zone}

On the basis of the pixel arrangement in the histogram, the final output map has been classified into "low", 
Fig. 7 Success and prediction rate curve for groundwater potential zones in Birbhum district, West Bengal

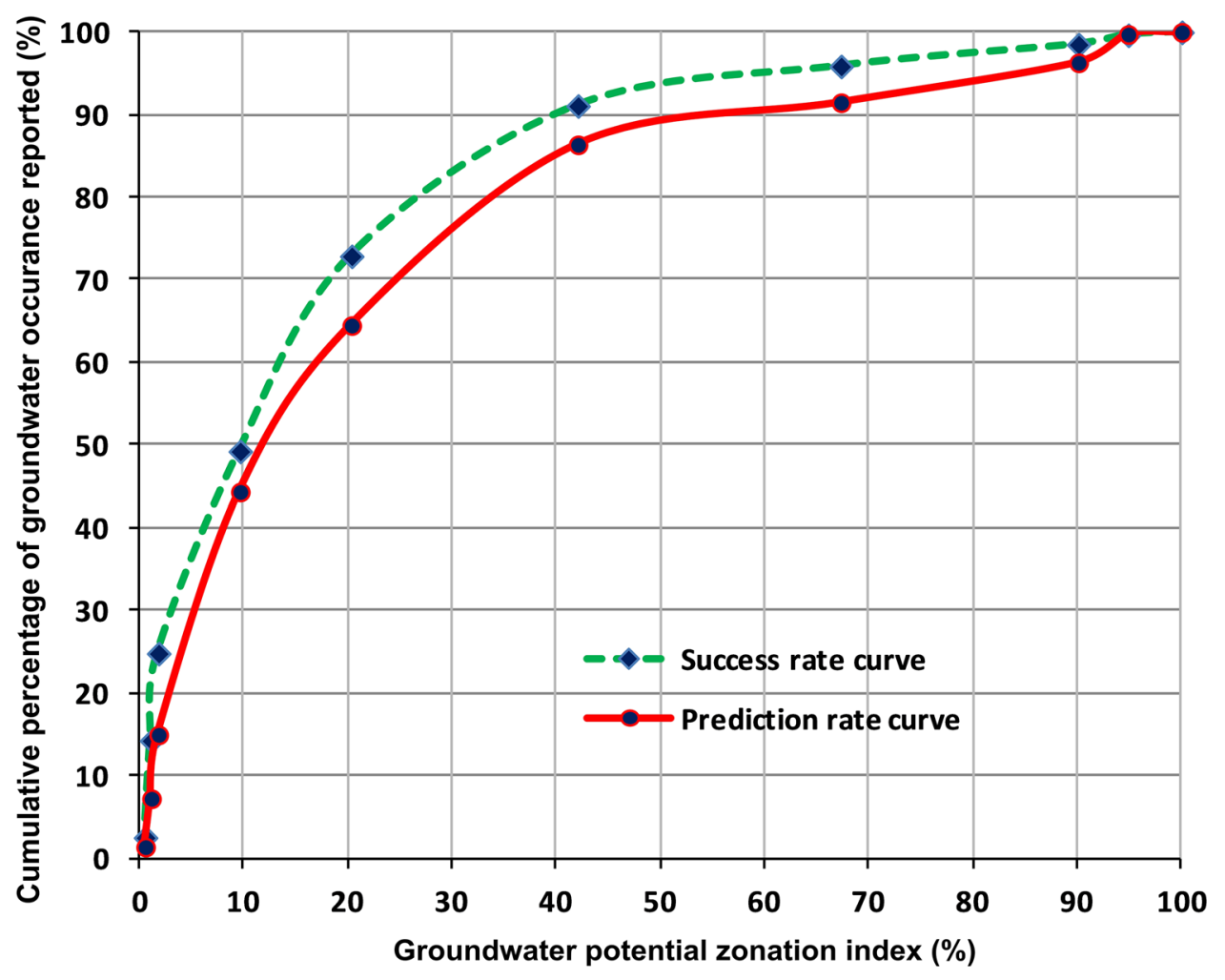

"medium", "high" and "very high" by means of selecting 'natural breaks/Jenks' in ArcGIS software (Fig. 5). About $18.41 \%$ of the total area covering an area $836.86 \mathrm{~km}^{2}$ falls under 'low' zone, $34.41 \% \quad\left(1563.98 \mathrm{~km}^{2}\right)$ falls under 'medium' groundwater potential zone, about $35.23 \%$ of the study area encompassing an area of $731.89 \mathrm{~km}^{2}$ falls under 'high' zone and $542.98 \mathrm{~km}^{2}(11.95 \%)$ of the total study area represents high groundwater potential area. The model generated output shows a mirror reflection of the principal factors like geomorphology, slope and geological formations underneath in controlling the potential groundwater zone. Southern and south-eastern parts of the study area including Sainthiya and Deocha region bear high groundwater potential zone due to the distribution of alluvial plains and agricultural land with high infiltration ability. Southwestern and western part of the study area represents low groundwater potential due to the presence of granite and basaltic hard rock underneath which have little influence on groundwater availability due to the low water holding potential and the absence of fracture/lineament density of the formation.

\section{Validation of the model}

The model generated output map of groundwater potential zone is further validated with the data related to yield potentialities of different borehole/tube well (CGWB report 1985) in the district. The pictorial representation of the reported location points is overlaid upon final groundwater potential zonation map and is represented in Fig. 6. The reported boreholes/tube wells data show good correlation with the final output map. Wells in Murarai, situated at northern extremities of the study area and Nalhati have a yield of $200 \mathrm{~m}^{3} / \mathrm{h}$. Some of the observation wells situated in Noapara, towards east along Murshidabad district, Benegram near Rampurhat and Dangapara have a yield of around $220 \mathrm{~m}^{3} / \mathrm{h}$. In the south-east region of the study area particularly near Ilam Bazar, the water level is quite shallow and yield is around $180-200 \mathrm{~m}^{3} / \mathrm{h}$. Heavy duty tube wells, located at Bara Dibur, Indradanga, Santiniketan, Mustal, etc. have a yield of about $72.7-179.7 \mathrm{~m}^{3} / \mathrm{h}$. The yield capacity in the hard rock terrain in the western and south-western part is very low $\left(\sim 4.5 \mathrm{~m}^{3} / \mathrm{d}\right)$.

Prediction and success rate (Chung and Fabbri 2003) is a widely used method for model validation. In the present study, this method of validation is implemented as the goodness of fit and success rate can be visualized distinctly (Klose et al. 2014). Initially, the reported groundwater potential yield inventory is divided into two datasets, i.e., modeling and validation set. To establish model's statistical robustness, $15 \%$ of reported groundwater potential data were randomly classified into validation group as suggested by Neuhäuser et al. 2012. The susceptible index values generated are divided into 100 equal classes each having a cumulative interval value of $1 \%$. Cumulative percentage of susceptible areas is plotted on the $x$-axis and the cumulative 
percentage of groundwater potential yield in the training dataset on the $y$-axis to generate the success rate curve (SRC) (Chung and Fabbri 2003; Van Westen et al. 2003; Sterlacchini et al. 2011). The SRC represents the prediction rate and lacks any information about the prediction accuracy hence to evaluate the future prediction accuracy, prediction rate curve (PRC) is also estimated. For generating of prediction rate curve (PRC), a method similar to $\mathrm{SRC}$ was followed except that on y-axis the groundwater potential yield in the test dataset was plotted (Chung and Fabbri 2003). The area under the curve (AUC) is measured for comparative and easier understanding of SRCs and PRCs generated. Assuming that the model is 'correct', success rates depict goodness of fits whereas prediction rates account for validation of the prediction. The area under the curve (AUC) for success rate (Fig. 7) indicates an accuracy of $83.03 \%$ whereas the prediction rate accounts for an accuracy of $78 \%$.

\section{Conclusion}

In this research work, combined application of remote sensing, GIS and MIF techniques are found an efficient tool in the delineation of groundwater potential zones in Birbhum district, West Bengal with respect to costs, efficiency, manpower and time involved in conversational exploration. Approximately, $47 \%$ of the total area falls from 'high' to 'very high' zones indicating that about half of the study area have good groundwater potential. The outcomes of the research will be helpful as first-hand information planners and local authorities for assessment, planning, management, administration, sustainable utilization and artificial recharging in near future.

Acknowledgements The authors express their heartiest gratitude to the DST (project No. SB/ES-687/2013 dated 11.11.2014), Government of India for financial support to the project. The author would also like to thank Central Ground Water Board, Survey of India, and Geological Survey of India for their help and support.

Open Access This article is distributed under the terms of the Creative Commons Attribution 4.0 International License (http:// creativecommons.org/licenses/by/4.0/), which permits unrestricted use, distribution, and reproduction in any medium, provided you give appropriate credit to the original author(s) and the source, provide a link to the Creative Commons license, and indicate if changes were made.

\section{References}

Abrahart RJ, See LM, Solomatine DP (2008) Practical Hydroinformatics. In: Abrahart RJ, See LM, Solomatine DP (eds) Computational intelligence and technological developments in water applications. Springer, Heidelberg, p 505. doi:10.1007/978-3540-79881-1

Adiat KAN, Nawawi MNM, Abdullah K (2012) Assessing the accuracy of GIS-based elementary multi criteria decision analysis as a spatial prediction tool-a case of predicting potential zones of sustainable groundwater resources. J Hydrol 440:75-89. doi:10.1016/j.jhydrol.2012.03.028

Arkoprovo B, Adarsa J, Prakash SS (2012) Delineation of groundwater potential zones using satellite remote sensing and geographic information system techniques: a case study from Ganjam district, Orissa, India. Res J Recent Sci 1(9):59-66

CGWB (1985) Central Groundwater Board (ER): Hydrogeology and groundwater resources of Birbhum district, West Bengal. Technical Report; Series D; No. 30

CGWB (2009) Central Groundwater Board: Bhu-Jal News-Quarterly Journal of Central Ground Water Board with the objective to disseminate information and highlight various activities and latest technical advances in the field of Ground Water. Q J 24(1):12-17

Chung CJF, Fabbri AG (2003) Validation of spatial prediction models for landslide hazard mapping. Nat Hazards 30:451-472. doi:10. 1023/B:NHAZ.0000007172.62651.2b

Dabral S, Sharma N, Bhatt B, Joshi JP (2013) A geospatial technique for demarcating ground water recharge potential zones: a study of Mahi-Narmada Inter stream region, Gujarat. IJGGS 4(1):177-185

Davoodi MD, Rezaei M, Pourghasemi HR, Pourtaghi ZS, Pradhan B (2015) Groundwater spring potential mapping using bivariate statistical model and GIS in the Taleghan watershed Iran. Arab J Geosci. doi:10.1007/s12517-013-1161-5

Dinesan VP, Gopinatha G, Ashitha MK (2015) Application of Geoinformatics for the Delineation of Groundwater Prospects Zones-a Case Study for Melattur Grama Panchayat in Kerala, India. International Conference on Water Resources, Coastal and Ocean Engineering (ICWRCOE '15). Aquatic Procedia, vol 4, pp 1389-1396

Hammouri NA, El-Naqa A, Barakat M (2012) An integrated approach to groundwater exploration using remote sensing and geographic information system. J Water Resour Prot 4(9):717-724. doi:10. 4236/jwarp.2012.49081

Jha MK, Chowdary VM, Chowdhury A (2010) Groundwater assessment in Salboni Block, West Bengal (India) using remote sensing, geographical information system and multi-criteria decision analysis techniques. Hydrogeol J 18:1713-1728. doi:10.1007/s10040-010-0631-z

Jothibasu A, Anbazhagan S (2016) Modeling groundwater probability index in Ponnaiyar River basin of South India using analytic hierarchy process. Model Earth Syst Environ 2:109. doi:10.1007/ s40808-016-0174

Kaliraj S, Chandrasekar N, Magesh NS (2014) Identification of potential groundwater recharge zones in vaigai upper basin, Tamil Nadu, using GIS-based analytical hierarchical process (AHP) technique. Arab J Geosci 7:1385-1401. doi:10.1007/ s12517-013-0849-x

Klose M, Gruber D, Damm B, Gerold G (2014) Spatial databases and GIS as tools for regional landslide susceptibility modeling. Zeitschrift für Geomorphologie NF 58(1):1-36. doi:10.1127/ 0372-8854/2013/0119

Krishnamurthy J, Mani A, Jayaraman V, Manivel M (2000) Groundwater resources development in hard rock terrain: an approach using remote sensing and GIS techniques. Int J Appl Earth Obs Geoinf 3(3-4):204-215. doi:10.1016/S03032434(00)85015-1

Lee S, Kim YS, Oh HJ (2012a) Application of a weights-of-evidence method and GIS to regional groundwater productivity potential

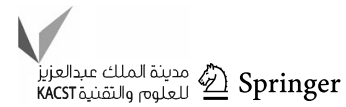


mapping. J Environ Manag 96(1):91-105. doi:10.1016/j. jenvman.2011.09.016

Lee S, Song KY, Kim Y, Park I (2012b) Regional groundwater productivity potential mapping using a geographic information system (GIS) based artificial neural network model. Hydrogeol J 20:1511-1527. doi:10.1007/s10040-012-0894-7

Machiwal D, Singh PK (2015) Comparing GIS-based multi-criteria decision-making and Boolean logic modelling approaches for delineating groundwater recharge zones. Arab Arabian J Geosci. doi:10.1007/s12517-015-2002-5

Machiwal D, Madan K, Jha MK, Bimal C, Mal BC (2011) Assessment of groundwater potential in a semi-arid region of India using remote sensing, GIS and MCDM techniques. Water Resour Manag 25:1359-1386. doi:10.1007/s11269-010-9749-y

Magesh NS, Chandrasekar N, Soundranayagam JP (2011) Morphometric evaluation of Papanasam and Manimuthar watersheds, parts of Western Ghats, Tirunelveli district, Tamil Nadu India: a GIS approach. Environ Earth Sci 64:373-381. doi:10.1007/ s12665-010-0860-4

Magesh NS, Chandrasekar N, Soundranayagam JP (2012) Delineation of groundwater potential zones in Theni district, Tamil Nadu, using remote sensing, GIS and MIF techniques. GSF 3(2):189-196. doi:10.1016/j.gsf.2011.10.007

Manap MA, Nampak H, Pradhan B, Lee S, Soleiman WNA, Ramli MF (2014) Application of probabilistic-based frequency ratio model in groundwater potential mapping using remote sensing data and GIS. Arab J Geosci. doi:10.1007/s12517-012-0795-Z

Mondal D, Gupta S, Reddy DV, Nagabhushanam P (2014) Geochemical controls on fluoride concentrations in groundwater from alluvial aquifers of the Birbhum district, West Bengal, India. J Geochem Explor 145:190-206. doi:10.1016/j.gexplo. 2014.06.005

Moore ID, Grayson RB, Ladson AR (1991) Digital terrain modelling: a review of hydrological, geomorphological, and biological applications. Hydrol Process 5(1):3-30. doi:10.1002/hyp. 3360050103

Mukherjee B, Rao MG, Karunakaran C (1969) Genesis of kaoline deposits of Birbhum, West Bengal, India. Clay Miner 8:161-170

Murthy KSR, Mamo AG (2009) Multi-criteria decision evaluation in groundwater zones identification in Moyale-Teltele subbasin, South Ethiopia. Int J Remote Sens 30:2729-2740. doi:10.1080/ 01431160802468255

Nag SK (2005) Applicatiion of lineament density and hydrogeomorphology to delineate groundwater potential zones of Baghmundi block in Purulia district, West Bengal. J Indian Soc Remote Sens 33(4):521-529. doi:10.1007/BF02990737

Nag SK, Ray S (2015) Deciphering groundwater potential zones using geospatial technology: a study in Bankura Block I and Block II, Bankura District, West Bengal. Arab J Sci Eng 40:205-214. doi:10.1007/s13369-014-1511-y

Naghibi SA, Pourghasemi HR, Dixon B (2016) Groundwater spring potential using boosted regression tree, classification and regression tree, and random forest machine learning models in Iran. Environ Monit Assess 188:44. doi:10.1007/s10661-0155049-6

Neuhäuser B, Damm B, Terhorst B (2012) GIS-based assessment of landslide susceptibility on the base of the weights-of-evidence model. Landslides 9:511-528. doi:10.1007/s10346-011-0305-5

PHED (Public Health Engineering Department) (2007) Government of West Bengal, Report. Activities \& achievements in rural drinking water supply and other areas. http://www.wbphed.gov. in/applications/im/uploads/000643.pdf. Accessed 18th Aug 2016

Pourtaghi ZS, Pourghasemi HR (2014) GIS-based groundwater spring potential assessment and mapping in the Birjand Township, southern Khorasan Province, Iran. Hydrogeol J 22:643-662. doi:10.1007/s10040-013-1089-6
Preeja KR, Sabu J, Jobin T, Vijith H (2011) Identification of groundwater potential zones of a tropical river basin (Kerala, India) using remote sensing and GIS techniques. J Indian Soc Remote Sens 39(1):83-94

Punmia BC, Jain AK, Jain AK (2005) Soil mechanics and foundations. Laxmi Publications (P) Ltd, New Delhi

Rassam DW, Pagendam DE, Hunter HM (2008) Conceptualisation and application of models for groundwater surface water interactions and nitrate attenuation potential in riparian zones. Environ Modell Softw 23:859-875. doi:10.1016/j.envsoft.2007. 11.003

Razandi Y, Pourghasemi HR, Samani-Neisani N, Rahmati O (2015) Application of analytical hierarchy process, frequency ratio, and certainty factor models for groundwater potential mapping using GIS. Earth Sci Inf 8(4):867-883. doi:10.1007/s12145-015-0220-8

Saunders RJ (2001) Artificial recharge of groundwater as a water management option for eastern Maine. M.Sc. thesis. BioResource Engineering, University of Maine, USA

Selvam S, Manimaran G, Sivasubramanian P, Balasubramanian N, Seshunarayana T (2014) GIS-based evaluation of water quality index of groundwater resources around Tuticorin coastal city, South India. Environ Earth Sci 71:2847-2867. doi:10.1007/ s12665-013-2662-y

Sen KK, Vijaya L (2005) Palynological study of the Dubrajpur formation in the Mesozoic Succession, Pachami area, Birbhum coalfield, West Bengal. J Palaeontol Soc India 50(1):121-133. http://palaeontologicalsociety.in/vol50_1/v8.pdf

Sen KK, Datta RK, Bandopadhaya SK (1987) Birbhum coalfield-a major coalfield discovered. In: Proceedings of the National Seminar on Coal Resources of India, pp 417-427

Senanayake IP, Dissanayake DMDOK, Mayadunna BB, Weerasekera WL (2016) An approach to delineate groundwater recharge potential sites in Ambalantota, Sri Lanka using GIS techniques. Geosci Front 7:115-124. doi:10.1016/j.gsf.2015.03.002

Senthil-Kumar GR, Shankar K (2014) Assessment of groundwater potential zones using GIS. Front Geosci 2(1):1-10

Shaban A, Khawlie M, Abdallah C (2006) Use of remote sensing and GIS to determine recharge potential zone: the case of Occidental Lebanon. Hydrogeol J 14(4):433-443. doi:10.1007/s10040-0050437-6

Singh P, Gupta A, Singh M (2014) Hydrological inferences from watershed analysis for water resource management using remote sensing and GIS techniques. Egypt J Remote Sens Space Sci 17:111-121. doi:10.1016/j.ejrs.2014.09.003

Singh A, Srivastav SK, Kumar S, Chakrapani GJ (2015) A modified DRASTIC model (DRASTICA) for assessment of groundwater vulnerability to pollution in an urbanized environment in Lucknow, India. Environ Earth Sci 74(7):5475-5490. doi:10. 1007/s12665-015-4558-5

Sterlacchini S, Ballabio C, Blahut J, Masetti M, Sorichetta A (2011) Spatial agreement of predicted patterns in landslide susceptibility maps. Geomorphology 125:51-61. doi:10.1016/j.geomorph. 2010.09.004

Taheri K, Gutiérrez F, Mohseni H, Raeisi E, Taheri M (2015) Sinkhole susceptibility mapping using the analytical hierarchy process (AHP) and magnitude-frequency relationships: a case study in Hamadan province, Iran. Geomorphology 234:64-79. doi:10.1016/j.geomorph.2015.01.005

Taheri K, Taheri M, Parise M (2016) Impact of intensive groundwater exploitation on an unprotected covered karst aquifer: a case study in Kermanshah Province, western Iran. Environ Earth Sci 75:122. doi:10.1007/s12665-016-5995-5

Tehrany MS, Pradhan B, Jebur MN (2013) Spatial prediction of flood susceptible areas using rule based decision tree (DT) and a novel ensemble bivariate and multivariate statistical models in GIS. J Hydrol 504(11):69-79. doi:10.1016/j.jhydrol.2013.09.034 
Thapa R, Gupta S, Reddy DV (2016) Application of geospatial modelling technique in delineation of fluoride contamination zones within Dwarka Basin, Birbhum, India. Geosci Front. doi:10.1016/j.gsf.2016.11.006

Thomas J, Joseph S, Thrivikramji K, Abe G, Kannan N (2012) Morphometrical analysis of two tropical mountain river basins of contrasting environmental settings, the southern Western Ghats, India. Environ Earth Sci 66(8):2353-2366. doi:10.1007/s12665011-1457-2

Umar Z, Pradhan B, Ahmad A, Jebur MN, Tehrany MS (2014) Earthquake induced landslide susceptibility mapping using an integrated ensemble frequency ratio and logistic regression models in West Sumatera Province, Indonesia. Catena 118:124-135. doi:10.1016/j.catena.2014.02.005

Van Westen CJ, Rengers N, Soeters R (2003) Use of geomorphological information in indirect landslide susceptibility assessment. Nat Hazards 30:399-419. doi:10.1023/B:NHAZ. 0000007097.42735.9e

Zabihi M, Pourghasemi HR, Pourtaghi ZS, Behzadfar M (2016) GISbased multivariate adaptive regression spline and random forest models for groundwater potential mapping in Iran. Environ Earth Sci 75:665. doi:10.1007/s12665-016-5424-9 